\title{
The Phytoestrogen Quercetin Impairs Steroidogenesis and Angiogenesis in Swine Granulosa Cells In Vitro
}

\author{
Sujen Eleonora Santini, Giuseppina Basini, Simona Bussolati, and Francesca Grasselli
}

Dipartimento di Produzioni Animali, Biotecnologie Veterinarie, Qualità e Sicurezza degli Alimenti-Sezione di Fisiologia Veterinaria, Università di Parma, Via del Taglio 10, 43126 Parma, Italy

Correspondence should be addressed to Giuseppina Basini, basini@unipr.it

Received 11 February 2009; Revised 7 April 2009; Accepted 22 April 2009

Recommended by Shoichiro Ono

\begin{abstract}
Experimental evidence documents that nutritional phytoestrogens may interact with reproductive functions but the exact mechanism of action is still controversial. Since quercetin is one of the main flavonoids in livestock nutrition, we evaluated its possible effects on cultured swine granulosa cell proliferation, steroidogenesis, and redox status. Moreover, since angiogenesis is essential for follicle development, the effect of the flavonoid on Vascular Endothelial Growth Factor output by granulosa cells was also taken into account. Our data evidence that quercetin does not affect granulosa cell growth while it inhibits progesterone production and modifies estradiol $17 \beta$ production in a dose-related manner. Additionally, the flavonoid interferes with the angiogenic process by inhibiting VEGF production as well as by altering redox status. Since steroidogenesis and angiogenesis are strictly involved in follicular development, these findings appear particularly relevant, pointing out a possible negative influence of quercetin on ovarian physiology. Therefore, the possible reproductive impact of the flavonoid should be carefully considered in animal nutrition.
\end{abstract}

Copyright ( 2009 Sujen Eleonora Santini et al. This is an open access article distributed under the Creative Commons Attribution License, which permits unrestricted use, distribution, and reproduction in any medium, provided the original work is properly cited.

\section{Introduction}

Quercetin (3,30,40,5,7-pentahydroxyflavone) is a flavonoid belonging to a group of plant-derived nonsteroidal compounds known as phytoestrogens [1]. In plants, these compounds are involved in energy production and exhibit strong antioxidant properties; in mammals, they have been shown to exert various biological and pharmacological effects $[2,3]$. Several studies [4-6] have demonstrated their significant health promoting activities, due to free radical scavenging and metal chelating properties. On the other hand, quercetin can also exhibit pro-oxidant effects [7]. It has been demonstrated [8-11] a relationship between quercetin free radical scavenging activity and its anticarcinogenic and anti-inflammatory properties. Most experimental data about the activity of flavonoids in different biological systems have been obtained by in vitro studies, and the knowledge of the pharmacokinetics and systemic availability of food-derived flavonoids in humans and animals is still incomplete: in particular, the bioavailability of quercetin appears low, but reported values range from $0 \%$ to $52 \%[12,13]$.
Recent data obtained in vitro or in animal studies indicate that flavonoids may also modify cell function independently of their antioxidant power [14-16], affecting the overall process of carcinogenesis by different mechanisms. Since it is well known that neovascularization represents a key process in tumor growth, invasion, and metastasis, a lot of scientific interest has developed in recent years about potential inhibitors of angiogenesis. Among natural health products, dietary flavonoids have shown to possess antiangiogenic effects, inhibiting several important steps of new vessel growth: an impairment of VEGF expression by different flavonoids has been documented $[17,18]$, as well as inhibitory effects on proliferation, migration, tube formation of endothelial cells in vitro [19-21].

In particular, many experimental evidences suggest a close link between quercetin antineoplastic effect and its antiangiogenic potential [22-25]. While both the antioxidant and antiangiogenic properties of quercetin are generally related to its protective effects against oxidative stress and should also be relevant for its cancer preventive impact $[11,26]$, the potential of the inhibition of vessel formation 
on female reproductive efficiency remains elusive; in fact, it is well known that the ovarian angiogenic process is strictly associated with follicular development [27]. Furthermore, ROSs play a crucial role in the ovarian follicle as signalling molecules in both the angiogenic cascade [28] and the ovulatory process. Additionally, phytoestrogens are able to bind to estrogen receptors thus activating several estrogenresponsive genes [3]. In particular, quercetin has been found to exhibit both estrogenic and antiestrogenic actions in vitro thus suggesting different potential effects on reproductive function.

Therefore, the aim of this study was to evaluate possible effects of quercetin on the function of granulosa cells, which play a complex and fundamental role in the development of the ovarian follicle. To this purpose, we studied the flavonoid action on granulosa cell proliferation, steroidogeneis, and redox status. Finally, since follicle growth requires new vessel formation, we also evaluated the effect of quercetin on the production of VEGF, the main proangiogenic factor.

\section{Materials and Methods}

All the reagents were obtained from Sigma (St. Louis, Mo, USA) unless otherwise specified.

2.1. Granulosa Cell Culture. Swine ovaries were collected at a local slaughterhouse, placed into cold $\mathrm{PBS}\left(4^{\circ} \mathrm{C}\right)$ supplemented with penicillin $(500 \mathrm{IU} / \mathrm{mL})$, streptomycin $(500 \mu \mathrm{g} / \mathrm{mL})$, and amphotericin $\mathrm{B}(3.75 \mu \mathrm{g} / \mathrm{mL})$, maintained in a freezer bag and transported to the laboratory within 1 hour. After two washings with PBS and ethanol (70\%), granulosa cells were aseptically harvested by aspiration from follicles $>5 \mathrm{~mm}$ with a 26-gauge needle and released in medium containing heparin $(50 \mathrm{IU} / \mathrm{mL})$, centrifuged for pelleting and then treated with $0.9 \%$ prewarmed ammonium chloride at $37^{\circ} \mathrm{C}$ for 1 minute to remove red blood cells. Cell number and viability were estimated using a haemocytometer under a phase contrast microscope after vital staining with trypan blue $(0.4 \%)$ of an aliquote of cell suspension. Cells were seeded at different densities (see below) in culture medium (CM) represented by M199 supplemented with sodium bicarbonate $(2.2 \mathrm{mg} / \mathrm{mL})$, bovine serum albumin $(0.1 \%)$, penicillin $(100 \mathrm{UI} / \mathrm{mL})$, streptomycin $(100 \mu \mathrm{g} / \mathrm{mL})$, amphotericin $\mathrm{B}(2.5 \mu \mathrm{g} / \mathrm{mL})$, selenium $(5 \mathrm{ng} / \mathrm{mL})$, and transferrin $(5 \mu \mathrm{g} / \mathrm{mL})$. Cells were treated with quercetin $\left(\mathrm{C}_{15} \mathrm{H}_{10} \mathrm{O}_{7}\right.$; CAS number $117-39-5$; purity $>95 \%$; Cayman Chemical, Michigan, USA) at the concentrations of 5 or $50 \mu \mathrm{g} / \mathrm{mL}$ and incubated at $37^{\circ} \mathrm{C}$ under humidified atmosphere $\left(5 \% \mathrm{CO}_{2}\right)$ for 48 hours.

Quercetin was dissolved in dimethyl sulfoxide (DMSO), and the final concentration of DMSO added to the medium was $0.2 \%$ ( $\mathrm{vol} / \mathrm{vol})$. The same concentration of DMSO was added to specific control wells.

2.2. Granulosa Cell Proliferation. Cell proliferation was evaluated by 5-bromo-2'-deoxyuridine (BrdU) incorporation assay test (Roche, Mannheim, Germany). Briefly, $10^{4}$ cell/200 $\mu \mathrm{L}$ CM were seeded in 96-well plates and treated as described above. After addition of $20 \mu \mathrm{L}$ BrdU to each well during the last 4 hour of incubation, culture media were removed, and DNA denaturing solution was added in order to improve the accessibility of the incorporate BrdU for antibody detection. Thereafter, $100 \mu \mathrm{L}$ anti-BrdU antibody were added to each well. After a 1.5-hour incubation at room temperature $\left(21^{\circ} \mathrm{C}\right)$, the immune complexes were detected by the subsequent substrate reaction. The reaction product was quantified by measuring the absorbance at $450 \mathrm{~nm}$ against $690 \mathrm{~nm}$ using Spectra Shell Microplate reader (SLT Spectra, Milan, Italy). To establish viable cell number, absorbance was related to a standard curve prepared by culturing in quintuplicate granulosa cells at different plating densities (from $10^{3}$ to $10^{5} / 200 \mu \mathrm{L}$ ) for 48 hours. The curve was repeated in four different experiments. The relationship between cell number and absorbance was linear $(r=0.92)$. Cell number/well was estimated from the resulting linear regression equation. The assay detection limit was $10^{3}$ cell/well, and the variation coefficient was less than $5 \%$. The number of cells obtained by this calculation was used for correcting hormones, VEGF production, and redox status data.

2.3. Steroid Production. Briefly, $10^{4}$ cells/well were seeded in 96-well plates in $200 \mu \mathrm{L} \mathrm{CM}$ supplemented with androstenedione $(28 \mathrm{ng} / \mathrm{mL})$ and treated with quercetin at concentrations previously described. Culture media were collected after incubation, frozen and stored at $-20^{\circ} \mathrm{C}$ until progesterone (P4) and $17 \beta$ estradiol (E2) determination by validated RIAs [29]. P4 assay sensitivity and ED50 were 0.24 and $1 \mathrm{nM} / \mathrm{L}$, respectively; E2 assay sensitivity and ED50 were 0.05 and $0.2 \mathrm{nM} / \mathrm{L}$. The intra- and interassay coefficients of variation were less than $12 \%$ for both assays.

\subsection{Measurement of Reactive Oxygen Species}

2.4.1. Nitric Oxide Production. Nitric oxide (NO) was assessed by measuring nitrite levels in culture media by microplate method based on the formation of a chromophore after reaction with Greiss reagent, which was prepared fresh daily by mixing equal volumes of stock A ( $1 \%$ sulfanilamide, $5 \%$ phosphoric acid) and stock B $(0.1 \%$ $\mathrm{N}$-[naphtyl] ethylenediamine dhydrochloride). Briefly, $10^{5}$ cells $/ 200 \mu \mathrm{L}$ CM were seeded in 96-well plates and treated with quercetin as already mentioned. After incubation with Greiss reagent, the absorbance was determined with a Spectra Shell Microplate Reader using a $540 \mathrm{~nm}$ against $620 \mathrm{~nm}$ filter. A calibration curve ranging from 25 to $0.39 \mu \mathrm{M}$ was prepared by diluting sodium nitrite in culture medium.

2.4.2. Superoxide Anion Production. Superoxide anion $\left(\mathrm{O}_{2}{ }^{-}\right)$ generation was measured by the cell proliferation WST-1 test (Roche, Mannheim, Germany). Briefly, $10^{5}$ cells $/ 200 \mu \mathrm{L}$ CM were seeded in 96-well plates and treated with quercetin as described above. Since evidence exists [30, 31] that tetrazolium salts can be used as a reliable measure of intracellular $\mathrm{O}_{2}{ }^{-}$production, $20 \mu \mathrm{L}$ of WST- 1 were added to the cell during the last 4 hours of incubation. The absorbance was then determined using a Spectra Shell Microplate reader at $450 \mathrm{~nm}$ against $620 \mathrm{~nm}$. 
2.4.3. Hydrogen Peroxide Production. Hydrogen peroxide $\left(\mathrm{H}_{2} \mathrm{O}_{2}\right)$ production was measured by an Amplex Red Hydrogen Peroxide Assay Kit (Molecular Probes, PoortGebouw, The Netherlands); the Amplex Red reagent reacts with $\mathrm{H}_{2} \mathrm{O}_{2}$ to produce resorufin, an oxidation product. Briefly, $2 \times 10^{5}$ cells $/ 200 \mu \mathrm{L}$ CM were seeded in 96-well plates. After incubation with treatments, plates were centrifuged for 10 minutes, at $400 \times \mathrm{g}$, then the supernatants were discarded and cells were lysed by adding cold Triton $1 \%$ in Tris- $\mathrm{HCl}$ (100 $\mu \mathrm{L}$ per well), incubating on ice for 30 minutes. The test was performed on cell lysates and read against a standard curve of $\mathrm{H}_{2} \mathrm{O}_{2}$ ranging from 0.195 to $12.5 \mu \mathrm{M}$. A Spectra Shell microplate reader set to read $540 \mathrm{~nm}$ emission was used to quantify the reaction product.

\subsection{Scavenging Enzyme Activity}

2.5.1. Superoxide Dismutase Activity. Superoxide dismutase (SOD) activity was determined by an SOD Assay Kit (Dojindo Molecular Technologies, Japan). Briefly, $2 \times 10^{5}$ cells $/ 200 \mu \mathrm{L}$ CM were seeded in 96-well plates and, after treatments, the plates were centrifuged for 10 minutes at $400 \times \mathrm{g}$. The supernatants were discarded and cells were lysed by adding cold Triton $1 \%$ in Tris- $\mathrm{HCl}\left(100 \mu \mathrm{L} / 10^{5}\right.$ cells $)$ and incubating on ice for 30 minutes. Cell lysates were tested without dilution, and a standard curve of SOD ranging from 0.156 to $20 \mathrm{U} / \mathrm{mL}$ was prepared. The colorimetric assay was performed measuring formazan produced by the reaction between a tetrazolium salt (WST-1) and a superoxide anion $\left(\mathrm{O}_{2}{ }^{-}\right)$, produced by the reaction of an exogenous xantine oxidase. The remaining $\mathrm{O}_{2}{ }^{-}$is an indirect hint of the endogenous SOD activity. The absorbance was determined with a Spectra Shell Microplate Reader reading at $450 \mathrm{~nm}$ against $620 \mathrm{~nm}$.

2.5.2. Peroxidase Activity. Peroxidase activity was measured by an Amplex Red Peroxidase Assay Kit (Molecular Probes, PoortGebouw, The Netherlands) based on the formation of an oxidation product (resorufin) derived from the reaction between $\mathrm{H}_{2} \mathrm{O}_{2}$ given in excess and the Amplex Red reagent. Briefly, $10^{5}$ cells $/ 200 \mu \mathrm{L} \mathrm{CM}$ were seeded in 96-well plates and incubated in the conditions described above. After centrifugation for 10 minutes. at $400 \times \mathrm{g}$, the supernatants were discarded, and cells were lysed by adding cold Triton $1 \%$ in TRIS $\mathrm{HCl}\left(100 \mu \mathrm{L} / 10^{5}\right.$ cells $)$ and incubating on ice for 30 minutes. Cell lysates were used undiluted to perform the test. The absorbance was determined with a Spectra Shell Microplate Reader using a $540 \mathrm{~nm}$ filter and read against a standard curve of peroxidase ranging from 0.039 to $5 \mathrm{mU} / \mathrm{mL}$.

\subsection{Scavenging Nonenzymatic Activity}

2.6.1. FRAP Assay. FRAP assay is a colorimetric method based on the ability of the antioxidant molecules to reduce ferric-tripiridyltriazine ( $\left.\mathrm{Fe}^{3+} \mathrm{TPTZ}\right)$ to a ferrous form $\left(\mathrm{Fe}^{2+} \mathrm{TPTZ}\right) . \mathrm{Fe}^{2+}$ is measured spectrophotometrically via determination of its coloured complex with 2,4,6-Tris(2pyridyl)-s-triazine ( $\left.\mathrm{Fe}^{2+} \mathrm{TPTZ}\right)$. TPTZ reagent was prepared before use, mixing $25 \mathrm{~mL}$ of acetate buffer, $2.5 \mathrm{~mL}$ of 2,4,6Tris(2-pyridyl)-s-triazine (TPTZ) $10 \mathrm{mM} / \mathrm{L}$ in $\mathrm{HCl} 40 \mathrm{mM} / \mathrm{L}$ and $\mathrm{FeCl}^{3-} 6 \mathrm{H}_{2} \mathrm{O}$ solution.

Briefly, $2 \times 10^{5}$ cells $/ 200 \mu \mathrm{L}$ CM were seeded in 96-well plates and treated as already described. At the end, plates were centrifuged for 10 minutes at $400 \times \mathrm{g}$, supernatants were discarded and cells were lysed by adding cold Triton $0.5 \%+$ PMSF in PBS $(200 \mu \mathrm{L} /$ well $)$, incubating on ice for 30 minutes. The test was performed on $40 \mu \mathrm{L}$ of cell lysates added to $\mathrm{Fe}^{3+}$ TPTZ reagent and then incubated at $37^{\circ} \mathrm{C}$ for 30 minutes. The absorbance of $\mathrm{Fe}^{2+} \mathrm{TPTZ}$ was determined by Spectra Shell Microplate Reader at $595 \mathrm{~nm}$. The ferric reducing ability of cell lysates was calculated by plotting a standard curve of absorbance against $\mathrm{FeSO}^{4-} 7 \mathrm{H}_{2} \mathrm{O}$ standard solution.

2.7. VEGF Production. The VEGF content in culture media was quantified by an ELISA (Quantikine, R \& D System, Minneapolis, Mich, USA); this assay, which was developed for human VEGF detection, has been validated for pig VEGF [32]. Briefly, $10^{6}$ cell/ $1 \mathrm{~mL}$ CM were seeded in 24-well plates and treated as described above. The assay sensitivity was $8.74 \mathrm{pg} / \mathrm{mL}$, and the intra and interassay CVs were always less than 7\%. The absorbance was determined with a Spectra Shell Microplate using a $450 \mathrm{~nm}$ filter.

2.8. Statistical Analysis. Each experiment was repeated at least 4 times (6 replicates/treatment). Experimental data are presented as mean \pm SEM; statistical differences were calculated with ANOVA using Statgraphics package (STSC Inc., Rockville, Md, USA). When significant differences were found, means were compared by Scheffè's F-test.

\section{Results}

3.1. Granulosa Cell Proliferation. BrdU incorporation assay test showed that basal swine granulosa cell proliferation was unaffected by both concentrations of quercetin.

3.2. Steroid Production. Basal steroid production by granulosa cells was $3.7 \pm 0.6$ and $71.8 \pm 10.0 \mathrm{ng} / \mathrm{mL}$ (mean \pm S.E.M.) for $\mathrm{E} 2$ and $\mathrm{P} 4$, respectively. $50 \mu \mathrm{g} / \mathrm{mL}$ quercetin significantly $(P<.001)$ inhibited $\mathrm{E} 2$ production by granulosa cells; on the contrary, $5 \mu \mathrm{g} / \mathrm{mL}$ significantly increased E2 levels (Figure 1). Quercetin significantly $(P<.001)$ inhibited $\mathrm{P} 4$ production by granulosa cells with a dose-dependent effect $(P<.001)$ (Figure 2$)$.

\subsection{Reactive Oxygen Species Production}

3.3.1. Nitric Oxide Production. In the control group, NO basal levels were $3.16 \pm 0.3 \mu \mathrm{M} ; 5 \mu \mathrm{g} / \mathrm{mL}$ quercetin significantly inhibited $(P<.001) \mathrm{NO}$ production, while $50 \mu \mathrm{g} / \mathrm{mL}$ significantly increased $(P<.001)$ NO levels in granulosa cell culture media (Figure 3 ).

3.3.2. Superoxide Anion Production. WST-1 assay showed that $50 \mu \mathrm{g} / \mathrm{mL}$ quercetin significantly $(P<.05)$ inhibited $\mathrm{O}_{2}{ }^{-}$ production, while $5 \mu \mathrm{g} / \mathrm{mL}$ were ineffective (Figure 4 ). 


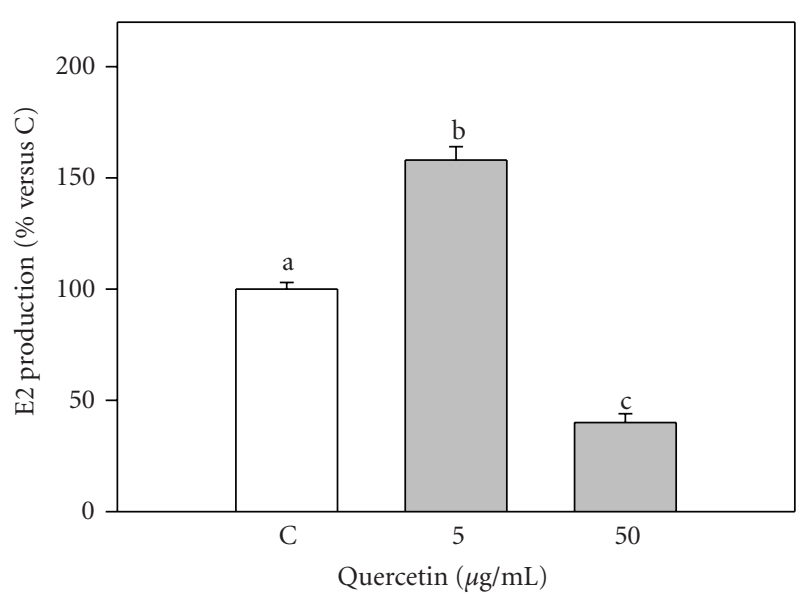

Figure 1: Effect of the 48-hour treatment with quercetin (5 and $50 \mu \mathrm{g} / \mathrm{mL}$ ) on Estradiol $17 \beta$ (E2) production by swine granulosa cell cultured in vitro. Data represent the mean \pm SEM of six replicates/treatment repeated in four different experiments. Different letters indicate significant differences $(P<.001)$ calculated by ANOVA and Scheffè's F-test (Statgraphics package, STSC Inc., Rockville, Md, USA).

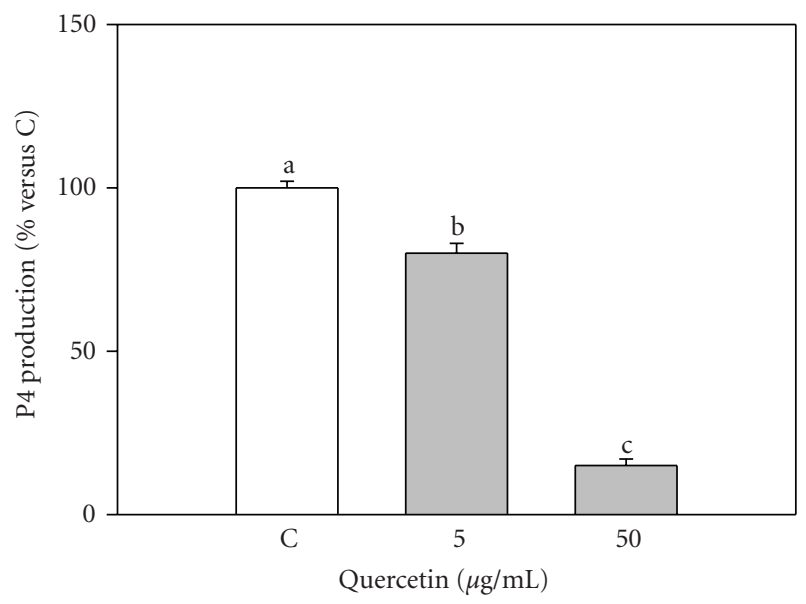

Figure 2: Effect of the 48-hour treatment with quercetin (5 and $50 \mu \mathrm{g} / \mathrm{mL}$ ) on progesterone (P4) production by swine granulosa cell cultured in vitro. Data represent the mean \pm SEM of six replicates/treatment repeated in four different experiments. Different letters indicate significant differences $(P<.001)$ calculated by ANOVA and Scheffè's F-test (Statgraphics package, STSC Inc., Rockville, Md, USA).

3.3.3. Hydrogen Peroxide Production. Colorimetric assay did not show any significant effect of quercetin on $\mathrm{H}_{2} \mathrm{O}_{2}$ production by swine granulosa cell.

\subsection{Scavenging Enzyme Activity}

Superoxide Dismutase and Peroxidase Activity. Both SOD and peroxidase activities were unaffected by quercetin.

\subsection{Scavenging Nonenzymatic Activity}

FRAP Assay. FRAP assay showed that $50 \mu \mathrm{g} / \mathrm{mL}$ quercetin significantly $(P<.001)$ increased the nonenzymatic antioxi-

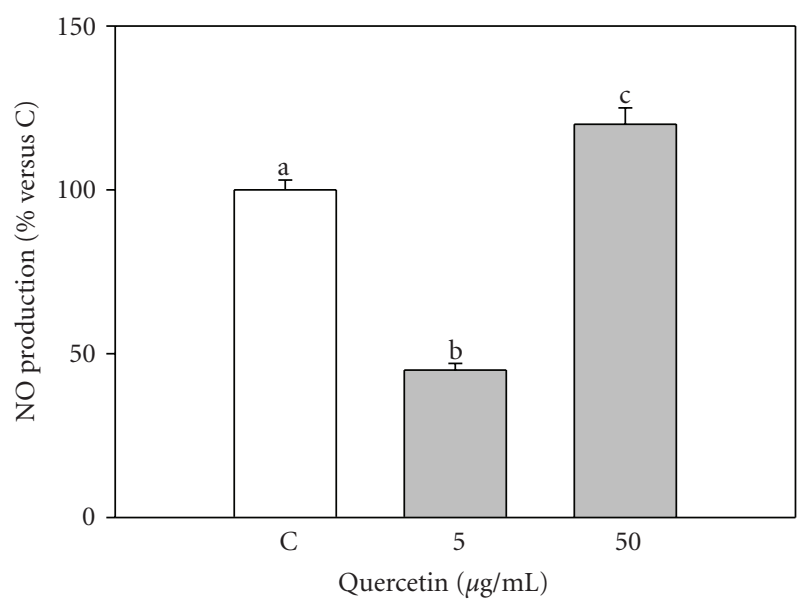

FIGURE 3: Effect of the 48-hour treatment with quercetin (5 and $50 \mu \mathrm{g} / \mathrm{ml}$ ) on nitric oxide production (NO) by swine granulosa cell cultured in vitro. Data represent the mean \pm SEM of six replicates/treatment repeated in four different experiments. Different letters indicate significant differences $(P<.001)$ calculated by ANOVA and Scheffè's F-test (Statgraphics package, STSC Inc., Rockville, Md, USA).

dant power in granulosa cell, while $5 \mu \mathrm{g} / \mathrm{mL}$ were ineffective (Figure 5).

3.6. VEGF Production. VEGF production by swine granulosa cell was significantly $(P<.05)$ inhibited by both concentrations of quercetin; higher dose produced more marked effects $(P<.001)$ (Figure 6).

\section{Discussion}

Phytoestrogen quercetin is abundant in many plants used in animal nutrition $[33,34]$. In recent years, this flavonoid has attracted a lot of interest, due to its putative health promoting activities likely resulting from its antioxidant effects. Nevertheless, its overall biological impact remains controversial, mostly because of limited information about its bioavailability, endogenous dynamics, and the relative contribution of different types of conjugates in humans and animals. Quercetin appears to be effective in in vitro assays at concentrations ranging from 0.3 and $30 \mu \mathrm{g} / \mathrm{mL}$, but plasma levels resulting from high oral doses are generally below those values [13]. This issue needs to be properly assessed in future studies, in order to get a better insight on the optimal consumption levels which could provide pharmacological significant concentrations in body fluids and tissues.

In our experimental model, high quercetin concentration $(30 \mu \mathrm{g} / \mathrm{ml})$ has also been tested, since a process of accumulation of this flavonoid in some body tissues cannot be excluded [13].

Present study confirms that quercetin can modulate ovarian function, interfering with porcine granulosa cell steroidogenic activity [35]. The negative effect on $\mathrm{P} 4$ production could result from an inhibition of steroidogenic enzymes [36, 37], since no detectable changes of cell proliferation have been observed. In a previous work [37], 


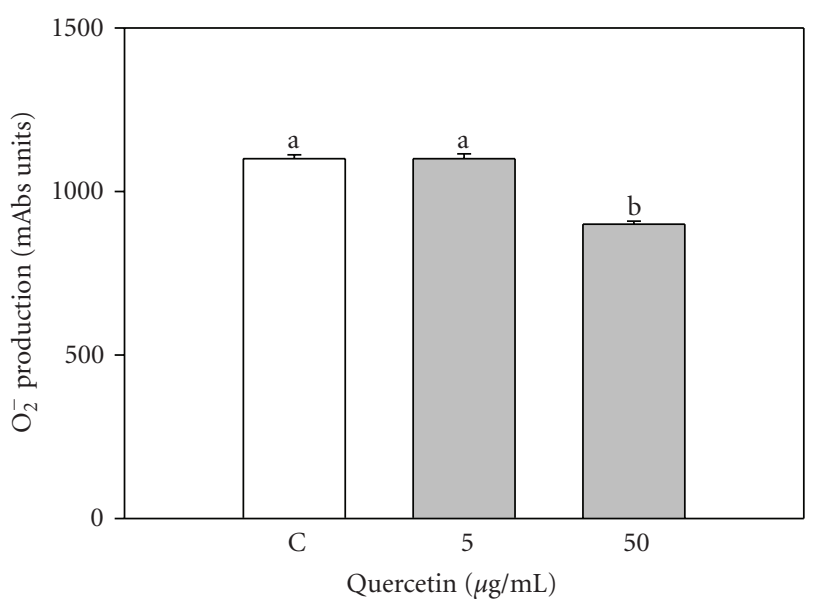

FIgURE 4: Effect of the 48-hour treatment with quercetin (5 and $50 \mu \mathrm{g} / \mathrm{ml})$ on superoxide anion $\left(\mathrm{O}_{2}{ }^{-}\right)$production by swine granulosa cell cultured in vitro. Data represent the mean \pm SEM of six replicates/treatment repeated in four different experiments. Different letters indicate significant differences $(P<.05)$ calculated by ANOVA and Scheffè's F-test (Statgraphics package, STSC Inc., Rockville, Md, USA).

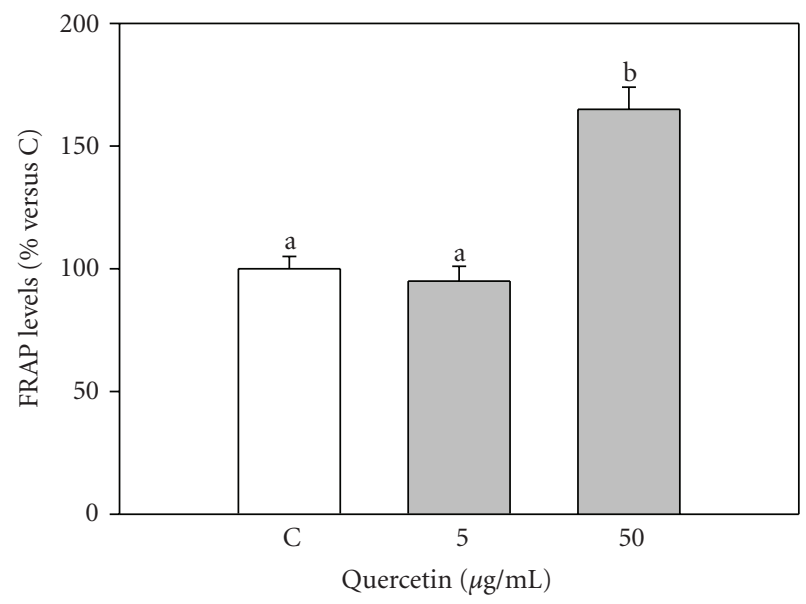

Figure 5: Effect of the 48-hour treatment with quercetin (5 and $50 \mu \mathrm{g} / \mathrm{ml}$ ) on Ferric Reducing Antioxidant Power (FRAP) levels in swine granulosa cell cultured in vitro. Data represent the mean \pm SEM of six replicates/treatment repeated in four different experiments. Different letters indicate significant differences $(P<$ $.001)$ calculated by ANOVA and Scheffè's F-test (Statgraphics package, STSC Inc., Rockville, Md, USA).

it has documented that a suppressive action of quercetin on cytochrome P45, catalyzing the conversion of cholesterol to pregnenolone, represents a rate-limiting step in the steroidogenic pathway. Several recent studies [35, 38, 39] show that the phytoestrogen-induced decrease of $\mathrm{P} 4$ production in granulosa cells could result from an inhibition of $3 \beta$ hydroxysteroid enzyme. On the contrary, Chen et al. [40] evidenced that quercetin increases StAR mRNA expression in MA-10 mouse tumor Leydig cells thus resulting in a stimulatory effect on steroidogenesis. This difference could be due to a cell type-dependent action of the flavonoid. As



Figure 6: Effect of the 48-hour treatment with quercetin (5 and $50 \mu \mathrm{g} / \mathrm{ml}$ ) on Vascular Endothelial Growth Factor (VEGF) production by swine granulosa cell cultured in vitro. Data represent the mean \pm SEM of six replicates/treatment repeated in four different experiments. Different letters indicate significant differences $(P<.001)$ calculated by ANOVA and Scheffè's F-test (Statgraphics package, STSC Inc., Rockville, Md, USA).

for E2 production, quercetin displayed a biphasic action: in fact, our data show that low dosages appear to increase E2 levels, while higher concentrations strongly decrease E2 production. An inhibitory effect of quercetin on aromatase activity in human granulosa-luteal cells has been documented [39], but the mechanisms through which this phytoestrogen could modulate the enzyme expression and activity remain elusive: these could involve either a binding with the estrogen receptors and/or a modulation of cell signalling pathways. On the basis of our data, it is possible to speculate that quercetin effects on E2 production by granulosa cells could be mediated by NO. In fact, this free radical seems to represent an autocrine regulator of granulosa cells E2 production [41], strongly inhibiting P450 aromatase activity [42]; the increase in estradiol secretion by cultured human granulosa cell [42] treated with NO synthase (NOS) inhibitors [43] would further strengthen this hypothesis. Interestingly, in agreement with our previous works [44, 45], current data document that quercetin at low doses strongly inhibits NO levels, while at higher doses it stimulates NO release. These overall data would indicate that quercetin can regulate aromatase activity, and thus E2 release, by an interference with the NO/NOS system in swine granulosa cells. Our results also document that the increase of NO levels after treatment with $50 \mu \mathrm{g} / \mathrm{mL}$ of quercetin is paralled by a decrease of $\mathrm{O}_{2}{ }^{-}$levels: this observation would suggest a possible relationship between these two ROSs. Quercetin has been shown [46] to protect nitric oxide (NO) from the scavenging actions of $\mathrm{O}_{2}{ }^{-}$; Vera et al. [47] reported that NO production negatively affects superoxide anion $\left(\mathrm{O}_{2}{ }^{-}\right)$accumulation with a resulting formation of peroxynitrite (ONOO). Even if the antioxidant potential of quercetin has been demonstrated by different studies [48, 49], pro-oxidative dose-dependent effects were also shown [7]. Present data indicate that quercetin does not 
affect neither $\mathrm{H}_{2} \mathrm{O}_{2}$ levels nor SOD activity. Since antioxidant scavenger gene expression depends mainly on ROS levels [50], both the inhibitory effect on $\mathrm{O}_{2}{ }^{-}$generation as well as the ineffectiveness in modulating $\mathrm{H}_{2} \mathrm{O}_{2}$ production could, respectively, explain the lack of effect on $\mathrm{SOD}$ and peroxidase enzyme activity. On the other hand, the higher quercetin concentration increased total nonenzymatic antioxidant ability thus suggesting that the antioxidant protection could result from an increased ability of several molecules to chelate transition metals [51].

Quercetin, at both concentrations tested, displayed a strong inhibitory effect on VEGF output thus suggesting its involvement in the modulation of angiogenesis. Since follicular development is strictly dependent on the angiogenic process [25], driven mainly by VEGF, this finding acquires particular relevance, since it is possible to speculate a possible negative influence of quercetin on ovarian physiology. In agreement with our findings, Zhong et al. [52] demonstrated that quercetin treatment significantly decreases VEGF secretion by myeloblastic leukemia cells NB4 in vitro. In addition, several studies document that flavonoids inhibit VEGFinduced endothelial cell functions and signalling pathways acting at molecular level [53-56]. Moreover, quercetin was found to inhibit several steps of angiogenesis, including proliferation, migration, and differentiation of endothelial cells $[20,57]$. In conclusion, the present study demonstrates that quercetin affects porcine granulosa cell function by interfering with steroidogenic activity and redox status as well as by inhibiting VEGF output; these data would suggest that this phytoestrogen represents a potential modulator of ovarian functions. Further studies are needed to better define the in vivo effects of quercetin on reproductive physiology.

\section{Acknowledgments}

This work was supported by FIL and PRIN grants.

\section{References}

[1] P. Moutsatsou, "The spectrum of phytoestrogens in nature: our knowledge is expanding," Hormones, vol. 6, no. 3, pp. 173193, 2007.

[2] S.-M. Kuo, "Flavonoids and gene expression in mammalian cells," Advances in Experimental Medicine and Biology, vol. 505, pp. 191-200, 2002.

[3] L. Dusza, R. Ciereszko, D. J. Skarzyński, et al., "Mechanism of phytoestrogens action in reproductive processes of mammals and birds," Reproductive Biology, vol. 6, supplement 1, pp. 151174, 2006.

[4] K. Vedavanam, S. Srijayanta, J. O’Reilly, A. Raman, and H. Wiseman, "Antioxidant action and potential antidiabetic properties of an isoflavonoid-containing soyabean phytochemical extract (SPE)," Phytotherapy Research, vol. 13, no. 7, pp. 601-608, 1999.

[5] G. A. Naderi, S. Asgary, N. Sarraf-Zadegan, and H. Shirvany, "Anti-oxidant effect of flavonoids on the susceptibility of LDL oxidation," Molecular and Cellular Biochemistry, vol. 246, no. 1-2, pp. 193-196, 2003.

[6] X. Tang, C. Zhang, W. Zeng, Y. Mi, and H. Liu, "Proliferating effects of the flavonoids daidzein and quercetin on cultured chicken primordial germ cells through antioxidant action," Cell Biology International, vol. 30, no. 5, pp. 445-451, 2006.

[7] A. W. Boots, H. Li, R. P. F. Schins, et al., "The quercetin paradox," Toxicology and Applied Pharmacology, vol. 222, no. 1, pp. 89-96, 2007.

[8] D. T. Zava and G. Duwe, "Estrogenic and antiproliferative properties of genistein and other flavonoids in human breast cancer cells in vitro," Nutrition and Cancer, vol. 27, no. 1, pp. 31-40, 1997.

[9] J. M. Wallace, "Nutritional and botanical modulation of the inflammatory cascade-eicosanoids, cyclooxygenases, and lipoxygenases - as an adjunct in cancer therapy," Integrative Cancer Therapies, vol. 1, no. 1, pp. 7-37, 2002.

[10] J. K. Jackson, T. Higo, W. L. Hunter, and H. M. Burt, "The antioxidants curcumin and quercetin inhibit inflammatory processes associated with arthritis," Inflammation Research, vol. 55, no. 4, pp. 168-175, 2006.

[11] Z.-P. Yuan, L.-J. Chen, L.-Y. Fan, et al., "Liposomal quercetin efficiently suppresses growth of solid tumors in murine models," Clinical Cancer Research, vol. 12, no. 10, pp. 31933199, 2006.

[12] E. U. Graefe, H. Derendorf, and M. Veit, "Pharmacokinetics and bioavailability of the flavonol quercetin in humans," International Journal of Clinical Pharmacology and Therapeutics, vol. 37, no. 5, pp. 219-233, 1999.

[13] P. Ader, A. Wessmann, and S. Wolffram, "Bioavailability and metabolism of the flavonol quercetin in the pig," Free Radical Biology and Medicine, vol. 28, no. 7, pp. 1056-1067, 2000.

[14] H. van der Woude, M. G. R. ter Veld, N. Jacobs, P. T. van der Saag, A. J. Murk, and I. M. C. M. Rietjens, "The stimulation of cell proliferation by quercetin is mediated by the estrogen receptor," Molecular Nutrition \& Food Research, vol. 49, no. 8, pp. 763-771, 2005.

[15] V. Cappelletti, P. Miodini, G. Di Fronzo, and M. G. Daidone, "Modulation of estrogen receptor- $\beta$ isoforms by phytoestrogens in breast cancer cells," International Journal of Oncology, vol. 28, no. 5, pp. 1185-1191, 2006.

[16] J.-D. Kim, L. Liu, W. Guo, and M. Meydani, "Chemical structure of flavonols in relation to modulation of angiogenesis and immune-endothelial cell adhesion," Journal of Nutritional Biochemistry, vol. 17, no. 3, pp. 165-176, 2006.

[17] S. Lamy, V. Bédard, D. Labbé, et al., "The dietary flavones apigenin and luteolin impair smooth muscle cell migration and VEGF expression through inhibition of PDGFR- $\beta$ phosphorylation," Cancer Prevention Research, vol. 1, no. 6, pp. 452-459, 2008.

[18] V. Singh-Gupta, H. Zhang, S. Banerjee, et al., "Radiationinduced HIF- $1 \alpha$ cell survival pathway is inhibited by soy isoflavones in prostate cancer cells," International Journal of Cancer, vol. 124, no. 7, pp. 1675-1684, 2009.

[19] D. M. Noonan, R. Benelli, and A. Albini, "Angiogenesis and cancer prevention: a vision," Recent Results in Cancer Research, vol. 174, pp. 219-224, 2007.

[20] H. Sogno, N. Vannini, G. Lorusso, et al., "Anti-angiogenic activity of a novel class of chemopreventive compounds: oleanic acid terpenoids," Recent Results in Cancer Research, vol. 181, pp. 209-212, 2009.

[21] V. Goulas, V. Exarchou, A. N. Troganis, et al., "Phytochemicals in olive-leaf extracts and their antiproliferative activity against cancer and endothelial cellsAnti-angiogenic activity of a novel class of chemopreventive compounds: oleanic acid terpenoids," Molecular Nutrition \& Food Research, vol. 53, pp. 600-608, 2009. 
[22] W. Tan, L. Lin, M. Li, et al., "Quercetin, a dietary-derived flavonoid, possesses antiangiogenic potential," European Journal of Pharmacology, vol. 459, no. 2-3, pp. 255-262, 2003.

[23] S. M. Sagar, D. Yance, and R. K. Wong, "Natural health products that inhibit angiogenesis: a potential source for investigational new agents to treat cancer-part 2," Current Oncology, vol. 13, no. 3, pp. 99-107, 2006.

[24] R. Kale, M. Saraf, A. Juvekar, and P. Tayade, "Decreased B16F10 melanoma growth and impaired tumour vascularization in BDF1 mice with quercetin-cyclodextrin binary system," Journal of Pharmacy and Pharmacology, vol. 58, no. 10, pp. 1351-1358, 2006.

[25] H. Hung, "Dietary quercetin inhibits proliferation of lung carcinoma cells," Forum of Nutrition, vol. 60, pp. 146-157, 2007.

[26] C. Kanadaswami, L.-T. Lee, P.-P. Lee, et al., "The antitumor activities of flavonoids," In Vivo, vol. 19, no. 5, pp. 895-909, 2005.

[27] H. M. Fraser, "Regulation of the ovarian follicular vasculature," Reproductive Biology and Endocrinology, vol. 4, article 18, pp. 1-9, 2006.

[28] G. Basini, F. Grasselli, F. Bianco, M. Tirelli, and C. Tamanini, "Effect of reduced oxygen tension on reactive oxygen species production and activity of antioxidant enzymes in swine granulosa cells," BioFactors, vol. 20, no. 2, pp. 61-69, 2004.

[29] F. Grasselli, M. Baratta, and C. Tamanini, "Effects of a GnRH analogue (buserelin) infused via osmotic minipumps on pituitary and ovarian activity of prepubertal heifers," Animal Reproduction Science, vol. 32, no. 3-4, pp. 153-161, 1993.

[30] L. Benov and I. Fridovich, "Is reduction of the sulfonated tetrazolium 2,3-bis (2-methoxy-4-nitro-5-sulfophenyl)-2tetrazolium 5-carboxanilide a reliable measure of intracellular superoxide production?" Analytical Biochemistry, vol. 310, no. 2, pp. 186-190, 2002.

[31] H. Ukeda, T. Shimamura, M. Tsubouchi, Y. Harada, Y. Nakai, and M. Sawamura, "Spectrophotometric assay of superoxide anion formed in Maillard reaction based on highly watersoluble tetrazolium salt," Analytical Sciences, vol. 18, no. 10, pp. 1151-1154, 2002.

[32] B. Barboni, M. Turriani, G. Galeati, et al., "Vascular endothelial growth factor production in growing pig antral follicles," Biology of Reproduction, vol. 63, no. 3, pp. 858-864, 2000.

[33] H. Wiseman, "The bioavailability of non-nutrient plant factors: dietary flavonoids and phyto-oestrogens," Proceedings of the Nutrition Society, vol. 58, no. 1, pp. 139-146, 1999.

[34] C. De Ruvo, R. Amodio, S. Algeri, et al., "Nutritional antioxidants as antidegenerative agents," International Journal of Developmental Neuroscience, vol. 18, no. 4-5, pp. 359-366, 2000.

[35] M. Lacey, J. Bohday, S. M. R. Fonseka, A. I. Ullah, and S. A. Whitehead, "Dose-response effects of phytoestrogens on the activity and expression of $3 \beta$-hydroxysteroid dehydrogenase and aromatase in human granulosa-luteal cells," The Journal of Steroid Biochemistry and Molecular Biology, vol. 96, no. 3-4, pp. 279-286, 2005.

[36] C. Pelissero, M. J. P. Lenczowski, D. Chinzi, B. DavailCuisset, J. P. Sumpter, and A. Fostier, "Effects of flavonoids on aromatase activity, an in vitro study," The Journal of Steroid Biochemistry and Molecular Biology, vol. 57, no. 3-4, pp. 215223, 1996.

[37] S. Rice, H. D. Mason, and S. A. Whitehead, "Phytoestrogens and their low dose combinations inhibit mRNA expression and activity of aromatase in human granulosa-luteal cells," The Journal of Steroid Biochemistry and Molecular Biology, vol. 101, no. 4-5, pp. 216-225, 2006.

[38] A. Krazeisen, R. Breitling, G. Möller, and J. Adamski, "Phytoestrogens inhibit human $17 \beta$-hydroxysteroid dehydrogenase type 5," Molecular and Cellular Endocrinology, vol. 171, no. 12, pp. 151-162, 2001.

[39] S. A. Whitehead and M. Lacey, "Phytoestrogens inhibit aromatase but not $17 \beta$-hydroxysteroid dehydrogenase (HSD) type 1 in human granulosa-luteal cells: evidence for FSH induction of 17 $\beta$-HSD," Human Reproduction, vol. 18, no. 3, pp. 487-494, 2003.

[40] Y.-C. Chen, M. L. Nagpal, D. M. Stocco, and T. Lin, "Effects of genistein, resveratrol, and quercetin on steroidogenesis and proliferation of MA-10 mouse Leydig tumor cells," Journal of Endocrinology, vol. 192, no. 3, pp. 527-537, 2007.

[41] B. J. Van Voorhis, M. S. Dunn, G. D. Snyder, and C. P. Weiner, "Nitric oxide: an autocrine regulator of human granulosaluteal cell steroidogenesis," Endocrinology, vol. 135, no. 5, pp. 1799-1806, 1994.

[42] G. D. Snyder, R. W. Holmes, J. N. Bates, and B. J. Van Voorhis, "Nitric oxide inhibits aromatase activity: mechanisms of action," The Journal of Steroid Biochemistry and Molecular Biology, vol. 58, no. 1, pp. 63-69, 1996.

[43] M. Masuda, T. Kubota, and T. Aso, "Effects of nitric oxide on steroidogenesis in porcine granulosa cells during different stages of follicular development," European Journal of Endocrinology, vol. 144, no. 3, pp. 303-308, 2001.

[44] G. Basini and C. Tamanini, "Interrelationship between nitric oxide and prostaglandins in bovine granulosa cells," Prostaglandins and Other Lipid Mediators, vol. 66, no. 3, pp. 179-202, 2001.

[45] F. Grasselli, N. Ponderato, G. Basini, and C. Tamanini, "Nitric oxide synthase expression and nitric oxide/cyclic GMP pathway in swine granulosa cells," Domestic Animal Endocrinology, vol. 20, no. 4, pp. 241-252, 2001.

[46] C. E. Rüfer and S. E. Kulling, "Antioxidant activity of isoflavones and their major metabolites using different in vitro assays," Journal of Agricultural and Food Chemistry, vol. 54, no. 8, pp. 2926-2931, 2006.

[47] R. Vera, M. Galisteo, I. C. Villar, et al., "Soy isoflavones improve endothelial function in spontaneously hypertensive rats in an estrogen-independent manner: role of nitric-oxide synthase, superoxide, and cyclooxygenase metabolites," The Journal of Pharmacology and Experimental Therapeutics, vol. 314, no. 3, pp. 1300-1309, 2005.

[48] V. Milovanović, N. Radulović, Z. Todorović, M. Stanković, and G. Stojanović, "Antioxidant, antimicrobial and genotoxicity screening of hydro-alcoholic extracts of five Serbian Equisetum species," Plant Foods for Human Nutrition, vol. 62, no. 3, pp. 113-119, 2007.

[49] C. Dufour, M. Loonis, and O. Dangles, "Inhibition of the peroxidation of linoleic acid by the flavonoid quercetin within their complex with human serum albumin," Free Radical Biology and Medicine, vol. 43, no. 2, pp. 241-252, 2007.

[50] J. G. Scandalios, "Oxidative stress: molecular perception and transduction of signals triggering antioxidant gene defenses," Brazilian Journal of Medical and Biological Research, vol. 38, no. 7, pp. 995-1014, 2005.

[51] M. Comporti, C. Signorini, G. Buonocore, and L. Ciccoli, "Iron release, oxidative stress and erythrocyte ageing," Free Radical Biology and Medicine, vol. 32, no. 7, pp. 568-576, 2002. 
[52] L. Zhong, F. Y. Chen, H. R. Wang, Y. Ten, C. Wang, and R. R. Ouyang, "Effects of quercetin on morphology and VEGF secretion of leukemia cells NB4 in vitro," Zhonghua Zhong Liu Za Zhi, vol. 28, no. 1, pp. 25-27, 2006.

[53] Y. Hasebe, K. Egawa, Y. Yamazaki, et al., "Specific inhibition of hypoxia-inducible factor (HIF)- $1 \alpha$ activation and of vascular endothelial growth factor (VEGF) production by flavonoids," Biological \& Pharmaceutical Bulletin, vol. 26, no. 10, pp. 13791383, 2003.

[54] M.-T. Lin, M.-L. Yen, C.-Y. Lin, and M.-L. Kuo, "Inhibition of vascular endothelial growth factor-induced angiogenesis by resveratrol through interruption of Src-dependent vascular endothelial cadherin tyrosine phosphorylation," Molecular Pharmacology, vol. 64, no. 5, pp. 1029-1036, 2003.

[55] E. Bagli, M. Stefaniotou, L. Morbidelli, et al., "Luteolin inhibits vascular endothelial growth factor-induced angiogenesis; inhibition of endothelial cell survival and proliferation by targeting phosphatidylinositol 3'-kinase activity," Cancer Research, vol. 64, no. 21, pp. 7936-7946, 2004.

[56] S.-H. Tseng, S.-M. Lin, J.-C. Chen, et al., "Resveratrol suppresses the angiogenesis and tumor growth of gliomas in rats," Clinical Cancer Research, vol. 10, no. 6, pp. 2190-2202, 2004.

[57] K. Igura, T. Ohta, Y. Kuroda, and K. Kaji, "Resveratrol and quercetin inhibit angiogenesis in vitro," Cancer Letters, vol. 171, no. 1, pp. 11-16, 2001. 

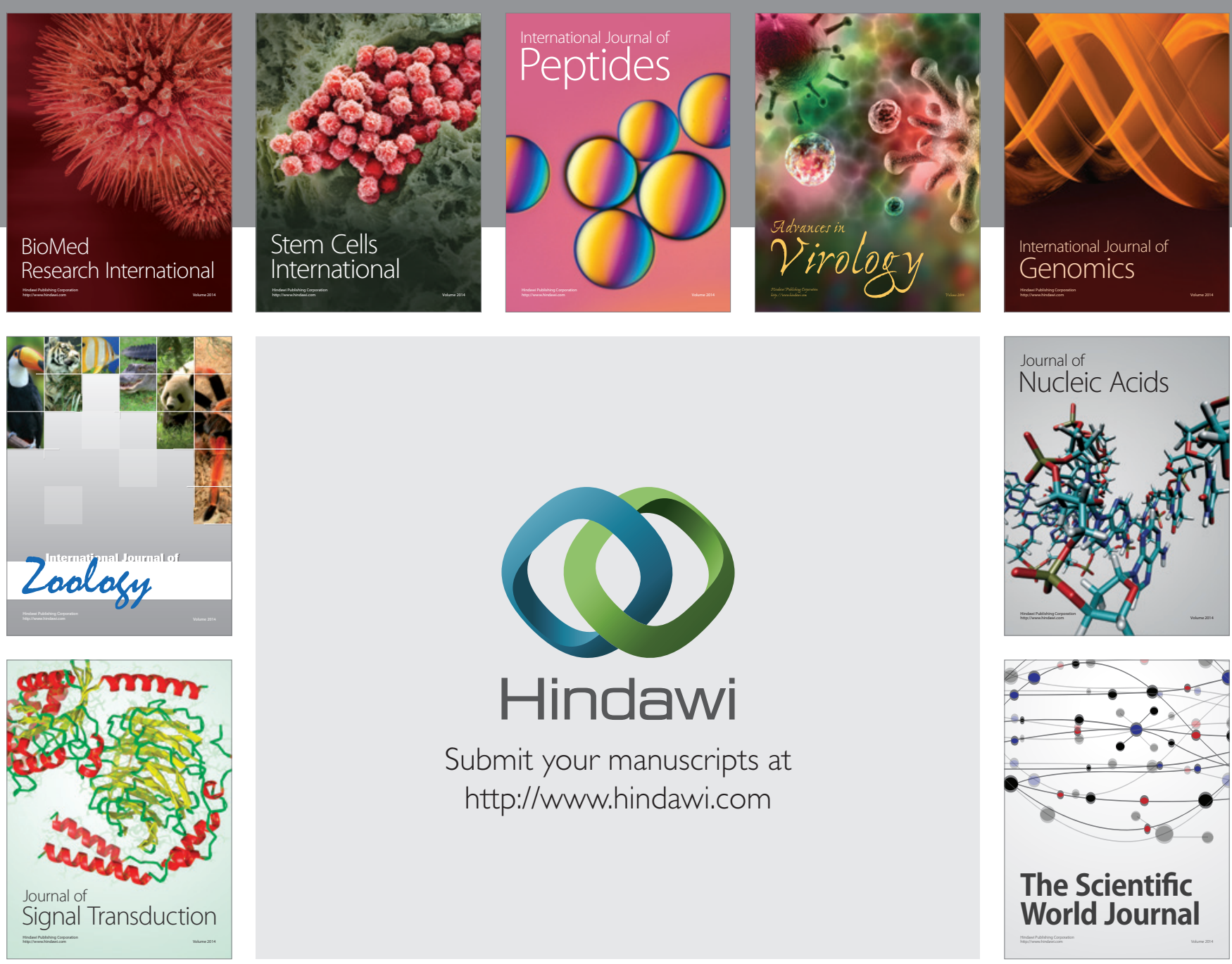

Submit your manuscripts at

http://www.hindawi.com
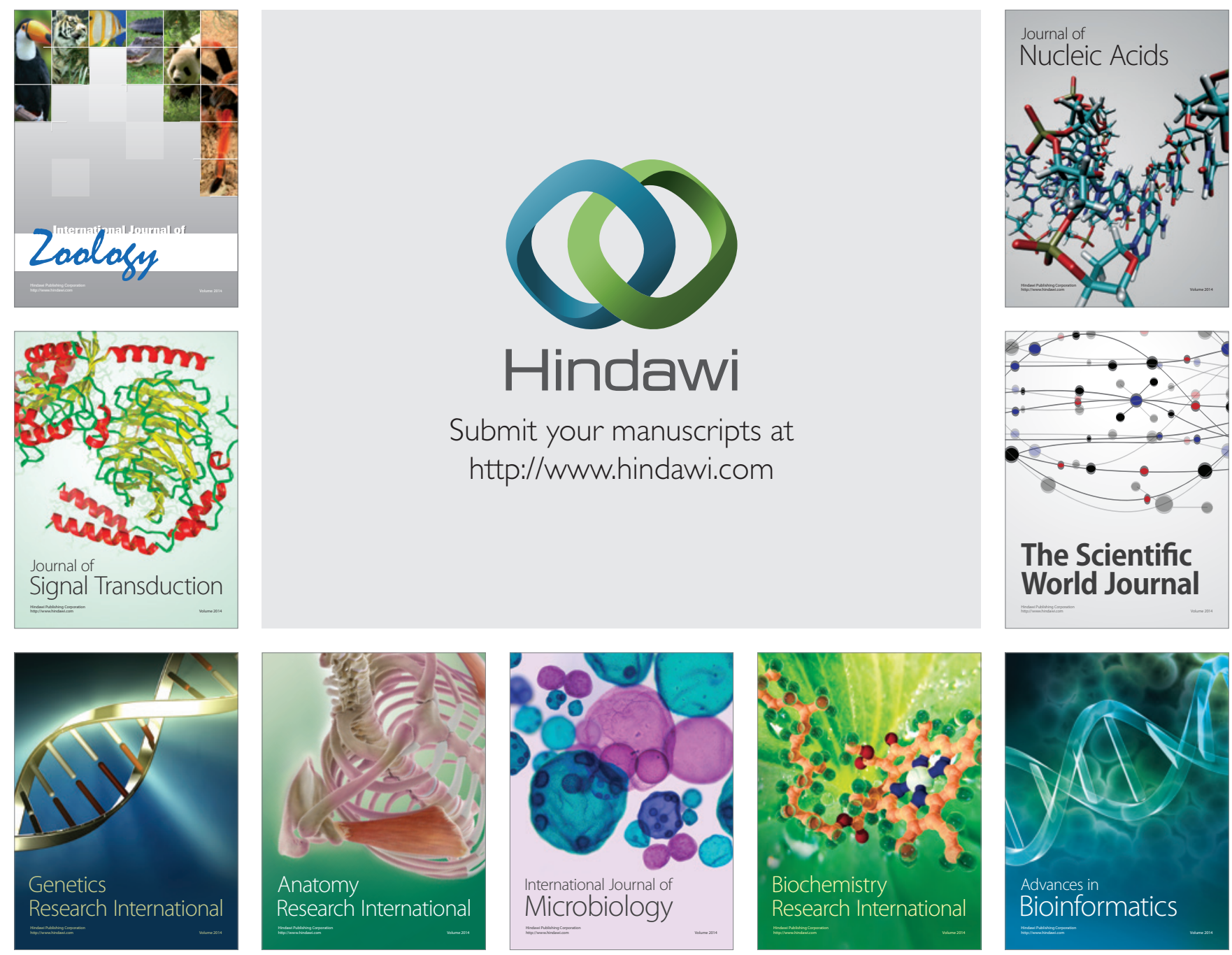

The Scientific World Journal
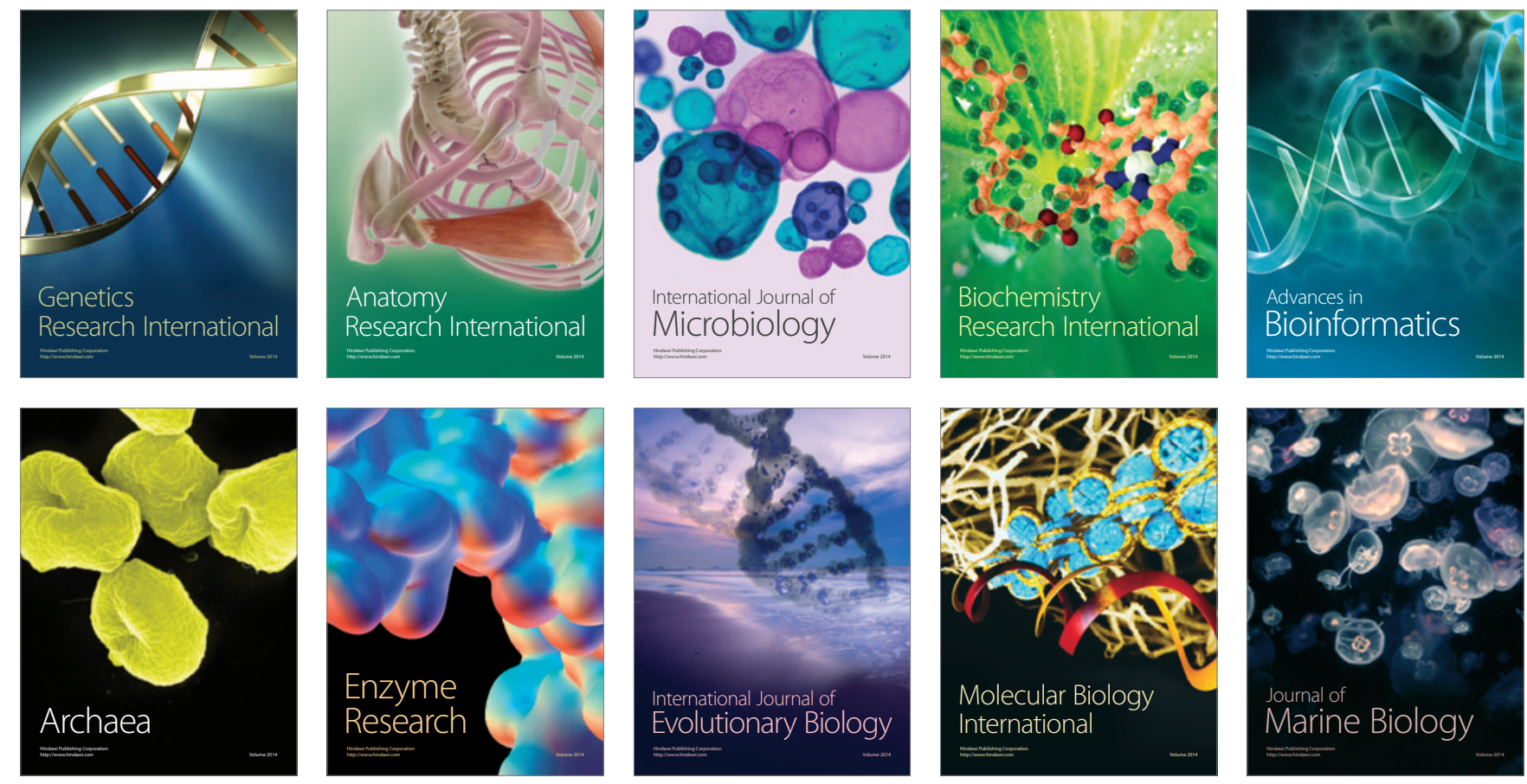